\title{
PTGIS wt Allele
}

National Cancer Institute

\section{Source}

National Cancer Institute. PT GIS wt Allele. NCI Thesaurus. Code C96439.

Human PT GIS wild-type allele is located in the vicinity of $20 q 13.13$ and is approximately $64 \mathrm{~kb}$ in length. This allele, which encodes prostacyclin synthase protein, is involved in prostaglandin biosynthesis. 